\title{
Presence and Activity of Various Amylases in Rice: Effect on Texture and Leached
}

\section{Sugar Composition during Cooking}

\author{
Yoshimasa TsuJII $^{1 *}$, Nanako NAGAFUKU ${ }^{2}$, Akira MiYAKE $^{2},{\text { Masataka } \text { UCHINO}^{2} \text { and Katsumi TAKANO }}^{2}$ \\ ${ }^{1}$ Alpha Foods Co., Ltd., Kitaaraki 645, Taisya-cho, Izumo-city, Shimane Prefecture 699-0722, Japan \\ ${ }^{2}$ Faculty of Applied Bioscience, Tokyo University of Agriculture, Sakuragaoka 1-1-1, Setagaya-ku, Tokyo 156-8502, Japan
}

Received May 16, 2012; Accepted October 17, 2012

\begin{abstract}
Amylase isozymes from non-glutinous japonica and indica rice types showed various band patterns, strengths and intensities based on zymography. Major bands were presumed to be $\alpha$ - and $\beta$-amylase according to their molecular weights; other amylases, 270 and $200 \mathrm{kDa}$ in size, were also detected. Three debranching enzymes (DBEs) were detected from the dye pattern as well. Amylase activities were observed at pH 7.0 during rice cooking. However, the $\alpha$-amylase activity at pH 7.0 was $50 \%$ lower than that at pH 5.0; DBE, $\beta$-amylase, and $\alpha$-glucosidase values were similarly reduced by $25 \%, 90 \%$ and $99 \%$, respectively. $\alpha$-Amylase activity and DBE activities correlated positively with both the amount of maltooligomer leached during rice cooking and the adhesiveness of cooked rice. Thus, it is considered that the activity of amylase isozymes affects the palatability of cooked rice. Therefore, enzymes from rice endosperm may represent a new and highly useful biomarker for evaluating the palatability of cooked rice.
\end{abstract}

Keywords: amylase, debranching enzyme, leached sugars, cooked rice, zymogram

\section{Introduction}

In general, the palatability of Japanese cooked rice is greatly affected by its texture; thus, sensory evaluation has long been used in assessing rice quality. The texture of cooked rice is affected by the chemical composition of the rice, mainly the amylose and protein content (Eksittikul et al., 1993). However, it is difficult to compare the taste of new rice and old rice on the basis of chemical composition. The lipid content of raw rice can be used as a biomarker of freshness. Lipid deterioration is the main factor responsible for odor generation and the inhibition of gelatinization, which has an effect on the taste of cooked rice (Chikubu, 1995). However, it is difficult to compare the taste among rice types on the basis of lipid characteristics. In order to determine the palatability of rice, PCR-based DNA analysis has been carried out and a new taste biomarker for cooked rice is expected to be determined using this technique (Ohtsubo et al., 2003).

Moreover, enzymes from milled rice endosperm are expected to function as a new biomarker for rice palatability.

*To whom correspondence should be addressed.

E-mail: tsujii-y@alpha-come.co.jp
For example, $\alpha$ - and $\beta$-amylases have been purified from milled rice; these enzymes are responsible for the production of oligosaccharides during rice cooking (Maruyama et al., 1981a,b). However, no detailed analysis of the synergy between enzymes from the endosperm has yet been performed.

These enzymes (i.e., $\alpha$ - and $\beta$-amylases, debranching enzymes (DBEs), and $\alpha$-glucosidase) are responsible for the conversion of biological materials and the generation of energy necessary for growth (Erwin and Paul, 1989). Multiple isoforms of $\alpha$-amylase are present in rice. There are at least $10 \alpha$-amylase genes in rice (Huang et al., 1992; Kim and Wu 1992; Yu et al., 1996; Mitsui and Itoh, 1997). More than 20 native $\alpha$-amylase isoforms have been identified and characterized in rice. Amylase from the endosperm of glutinous rice was reported to exhibit characteristics and activity that differ among rice cultivars (Tsujii et al., 2007). $\beta$-Amylase is only synthesized in the aleurone cells, and its production in embryo-less half-seeds is not under hormonal control (Yamaguchi et al., 1999). There are two types of DBEs, namely isoamylase and pullulanase, which have been purified from the developing rice endosperm (Fujita et al., 1999; Nakamura et al., 1996). These enzymes remove unnecessary $\alpha-1,6-$ glucosidic linkages at improper positions apart from the 
densely branched regions of a cluster of amylopectin (Nakamura, 2002). It was shown that the DNAs amplified by PCR, using primers designed for debranching enzymes (DBE), revealed marked differences between japonica and indica subspecies of rice (Nakamura et al., 2004). $\alpha$-Glucosidase has been purified from various rice cultivars (Oryza sativa L.), namely Nipponbare (Nakai et al., 2007), Koshihikari (Awazuhara et al., 2000), Onnemochi (Ito et al., 1989), Shinsestsu (Takahashi et al., 1971), and Yashiromochi (Yamasaki and Suzuki, 1997), and from the germinating seeds of Thai rice (Eksittikul et al., 1993). The action of $\alpha$-glucosidase may affect the accumulation of glucose during rice cooking (Mahashi et al., 2010).

In this study, we determined the texture of cooked rice, the amount of leached sugars during rice cooking, and $\alpha$-amylase, $\beta$-amylase, $\alpha$-glucosidase and DBE activities from the zymograms, and reported on the relationships among them.

\section{Materials and Methods}

Rice samples and preparation Different varieties of non-glutinous short-grain japonica rice (i.e., Koshihikari, Nipponbare, Takitate and Chinese 294 (C294)), non-glutinous medium-grain japonica rice (i.e., M401 and Calrose), and non-glutinous long-grain indica rice (Thailand White Rice, TWR) were used. Rice samples were stored at $4^{\circ} \mathrm{C}$ until analysis. Before enzyme extraction, rice was milled using a mixer-type rice-milling machine (MR-D500 Twinbird Co., Tsubame, Japan) to obtain a 90\% (degree of polish) milling yield. Rice samples were obtained directly from a wholesaler in Tokyo, Japan (Kitoku Shinryo Co., Ltd.). In this study, a variety of rice commonly consumed in Japan (i.e., Koshihikari, Nipponbare (standard) and Takitate (low amylose content)), USA (M202 and L205), China (Chinese 294) and Thailand (TWR) were selected.

Extraction of crude enzyme Milled rice was added to water in a ratio of 1:1.8 and the mixture was left at room temperature for $1 \mathrm{~h}$. The mixture was homogenized $(15,000$ rpm, $3 \mathrm{~min}$; NS-51K, Microtec Co., Chiba, Japan) and placed in a reciprocal shaker for $1 \mathrm{~h}$. Then, the precipitate was removed by centrifugation at $18,000 \times g$ for $30 \mathrm{~min}$. The supernatant was used as the crude enzyme for the determination of enzyme properties. All the processes were carried out at $4^{\circ} \mathrm{C}$. Total protein content was measured by the Bradford assay (Bradford, 1976).

Detection of amylase on zymograms Amylase activity was detected by SDS-PAGE using a 10\% polyacrylamide gel containing $1.0 \%$ soluble starch (Nacalai Tesque, Inc., Kyoto, Japan, following the procedure described by Laemmli (Laemmli, 1970), with some modifications. Electrophoresis was carried out at $4^{\circ} \mathrm{C}$, and SDS was removed using $2.5 \%$ Triton X-100 (Yamagata et al., 1988). The gels were incubated at $37^{\circ} \mathrm{C}$ overnight in $100 \mathrm{mM}$ Mcllvain buffer ( $\mathrm{pH} \mathrm{5.0)}$ containing $10 \mathrm{mM} \mathrm{CaCl}_{2}$, and then stained with $0.01 \%$ (w/ v) $\mathrm{I}_{2} / 0.1 \%(\mathrm{w} / \mathrm{v}) \mathrm{KI}$ solution. A clear band indicated amylase activity and a blue band indicated DBE activity.

Enzyme assay $\alpha$-Amylase activity was assayed following the cereal $\alpha$-amylase assay reagent method (Megazyme International Ireland, Wicklow, Ireland.) (McCleary and Sheehan, 1987; Sheehan and McCleary, 1988). After 60 min of incubation at $37^{\circ} \mathrm{C}(\mathrm{pH} 5.0$ and 7.0$)$, the reaction was stopped. One unit (U) of $\alpha$-amylase activity is defined as the amount of enzyme required to release one micromole of $p$ nitrophenol in $1 \mathrm{~min}$ under the defined assay conditions.

$\beta$-Amylase activity was assayed using a $500 \mu \mathrm{L}$ reaction mixture containing 1.0\% soluble starch, $200 \mathrm{mM}$ Mcllvaine buffer ( $\mathrm{pH} 5.0$ and 7.0), and an appropriate dilution of the enzyme preparation. After $30 \mathrm{~min}$ of incubation at $37^{\circ} \mathrm{C}$, the reaction was stopped and the amount of residual sugars was measured by the Somogyi-Nelson method (Nelson, 1944; Somogyi, 1952). One unit (U) of $\beta$-amylase activity is defined as the amount of enzyme required to release one micromole of reducing sugars in 1 min under the defined assay conditions.

$\alpha$-Glucosidase activity was assayed using a $500 \mu \mathrm{L}$ reaction mixture containing $5 \mathrm{mM} p$-nitrophenyl- $\alpha$-Dglucopyranoside (Sigma-Aldrich Corp.St. Louis, MO, USA), $200 \mathrm{mM}$ Mcllvaine buffer (pH 5.0 and 7.0), and an appropriate dilution of the enzyme preparation. After $30 \mathrm{~min}$ of incubation at $50^{\circ} \mathrm{C}$, the reaction was stopped by adding 100 $\mathrm{mM} \mathrm{Na} \mathrm{CO}_{3}$ and the amount of $p$-nitrophenol released was monitored. One unit (U) of $\alpha$-glucosidase activity is defined as described previously for $\alpha$-amylase activity.

DBE activity was assayed using a $500 \mu \mathrm{L}$ reaction mixture containing $1.0 \%$ pullulan, $200 \mathrm{mM}$ Mcllvaine buffer (pH 5.0 and 7.0), and an appropriate dilution of the enzyme preparation. After $30 \mathrm{~min}$ of incubation at $40^{\circ} \mathrm{C}$, the reaction was stopped and the amount of residual sugars was measured by the Somogyi-Nelson method. One unit (U) of DBE activity is defined as the amount of enzyme required to release one micromole of maltotriose in 1 min under the defined assay conditions.

Leached sugars during rice cooking Leached sugars during rice cooking were measured using the method of Chikuu et al. (1995). Samples (8 g) in stainless-steel baskets $(\phi 40 \times 75 \mathrm{~mm})$ were boiled in $160 \mathrm{~mL}$ of pure water for $20 \mathrm{~min}$, drained for $10 \mathrm{~min}$, and then weighed. The height of each sample was measured immediately after weighing. Cooking water $(200 \mathrm{~mL})$ was added and total sugars were measured by the phenol-sulfuric acid method (Dubois et al., 
1956); the amount of residual sugar was also measured. The cooking water was freeze-dried and $80 \%$ ethanol-soluble carbohydrate was obtained. Oligosaccharides were labeled with 4-aminobenzoic acid octylester (ABOE) using an ABOE labeling kit (J-OIL MILLS, Inc. Tokyo, Japan). ABOEderivatized oligosaccharides were separated by reverse-phase HPLC according to the manufacturer's instructions. The ABOE-glucose oligomer (J-OIL MILLS, Inc. Tokyo, Japan) was used as the standard (Ikekita et al., 1997; Murata et al., 1997a,b). Area ratio was calculated from the chromatogram of the total carbohydrate to determine the degrees of polymerization (DP), from $1-20$.

Texture of cooked rice Milled rice samples (10 g) were placed in aluminum cups $(\phi 42 \times 40 \mathrm{~mm})$. Prior to cooking, rice was soaked in $16 \mathrm{~g}$ of pure water at room temperature $\left(25^{\circ} \mathrm{C}\right)$ for $1 \mathrm{~h}$, and then cooked in an ordinary electric rice cooker (SR-3100, National Co., Tokyo, Japan). Cooked rice samples were kept in the rice cooker for about $2 \mathrm{~h}$ at room temperature $\left(25^{\circ} \mathrm{C}\right)$ before measurements. The hardness and stickiness of cooked milled rice samples were measured with a creep meter (RE2-33005 II, Yamaden Co., Tokyo). The conditions for measurements were as follows: using a stainless steel circular plunger $(\phi 40 \mathrm{~mm})$ at a speed of $0.5 \mathrm{~mm} /$ s, samples were compressed at a clearance height of $17 \mathrm{~mm}$. Each measurement was conducted 10 times (20 cups) and expressed as the average result.

Statistical analysis Analysis of variance was conducted using Statcel software (OMS Publishing Inc., Saitama, Japan). Data were subjected to analysis of variance followed by Fisher's PLSD test to compare means at $p<0.05$. Pearson's correlation coefficient was also calculated (Yanai, 1998).

\section{Results}

Electropherogram of amylases in milled rice The amylase isozyme patterns of the different rice samples obtained by SDS-PAGE are presented in Figure 1. The amylase, indicated by a clear band, was resolved into four isozymes (I, II, III and IV) with estimated molecular weights of 270, 200, 140 and $44 \mathrm{kDa}$, respectively. DBE, which is indicated by a slightly darker band, was resolved into three isozymes (i, ii and iii) with molecular weights of approximately 75 , 67 and $57 \mathrm{kDa}$, respectively. The isozyme pattern differed among samples as follows: DBE isozyme i was not detected in M401. Isozymes IV and I were not detected in TWR. In addition, band intensity varied among the samples. Amylase isozyme IV was only slightly observed in Koshihikari, Calrose and TWR rice varieties, but it was strongly present in all other samples. All amylase-associated bands in TWR were weakly observed compared to other samples.

Enzyme activity The activities of the evaluated en-

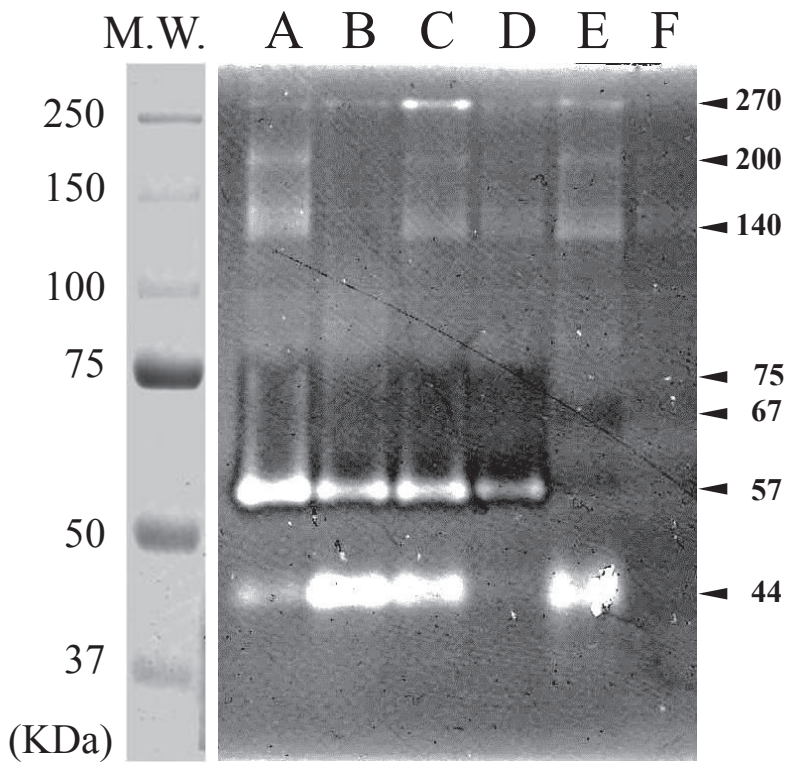

Fig. 1. Zymogram of amylases from milled non-glutinous japonica and indica rice varieties. Amylase activity was detected by SDSPAGE containing $1.0 \%$ soluble starch. The gels were incubated at $37^{\circ} \mathrm{C}$ overnight in $100 \mathrm{mM}$ Mcllvain buffer (pH 5.0) containing 10 $\mathrm{mM} \mathrm{CaCl}_{2}$. They were stained with $0.01 \%(\mathrm{w} / \mathrm{v}) \mathrm{I} 2 / 0.1 \%(\mathrm{w} / \mathrm{v}) \mathrm{KI}$ solution. A clear band indicated amylase activity and a blue band indicated DBE activity.

$\mathrm{A}=$ Koshihikari, $\mathrm{B}=$ Nipponbare, $\mathrm{C}=$ Takitate, $\mathrm{D}=$ Calrose, $\mathrm{E}=$ M401, F =TWR (Thailand white Rice)

zymes are shown in Table 1. Enzyme activity at pH 7.0 was examined during rice cooking. The $\alpha$-amylase activity of milled rice ranged from 15 to $88 \mathrm{U} / \mathrm{g}$; the Takitate rice variety showed the highest $\alpha$-amylase activity among all the samples. On the other hand, at $\mathrm{pH} 5.0$ the $\alpha$-amylase activity ranged from 21 to $160 \mathrm{U} / \mathrm{g}$; the Koshihikari variety presented the highest activity. In general, enzyme activities at $\mathrm{pH} 7.0$ were lower than those at $\mathrm{pH} 5.0$ for all samples. Differences in the taste of the cooked rice samples could be attributed to these results.

A narrow range of $\beta$-amylase activity of milled rice was observed: $0.053-0.089 \mathrm{U} / \mathrm{g}$ and $0.34-0.80 \mathrm{U} / \mathrm{g}$ at $\mathrm{pH} 7.0$ and 5.0, respectively. The highest $\beta$-amylase activity was observed in Takitate and TWR varieties at $\mathrm{pH}$ 7.0, and for Koshihikari at $\mathrm{pH}$ 5.0. The activity at $\mathrm{pH} 7.0$ was approximately $1 / 10$ of that observed at $\mathrm{pH} 5.0$. At $\mathrm{pH} 7.0$, no difference in activity was observed among samples. A narrow range of $\alpha$-glucosidase activity of milled rice was observed: $2.5-4.7$ $\mathrm{U} / \mathrm{g}$ and $207-243 \mathrm{U} / \mathrm{g}$ at $\mathrm{pH} 7.0$ and 5.0, respectively. The activities at $\mathrm{pH} 7.0$ were approximately $1 / 100$ of those at $\mathrm{pH}$ 5.0 , and no significant differences in $\alpha$-glucosidase activity among samples were observed.

The DBE activity of milled rice ranged from $0.18-2.86$ $\mathrm{U} / \mathrm{g}$ at $\mathrm{pH} 7.0$ and from $0.53-2.67 \mathrm{U} / \mathrm{g}$ at $\mathrm{pH}$ 5.0. The TWR variety presented significantly low DBE activity compared 
Table 1. Comparison of enzyme activities for samples. Enzyme activity was examined at $\mathrm{pH} 7.0$ during rice cooking and at $\mathrm{pH} 5.0$ near optimum $\mathrm{pH}$ of the rice endosperm enzyme. Means in the same column with the same superscript are not significantly different at $p<0.05$ by LSD test.

TWR $=$ Thailand White Rice

\begin{tabular}{|c|c|c|c|c|c|c|c|c|}
\hline & \multicolumn{2}{|c|}{$\alpha$-Amylase } & \multicolumn{2}{|c|}{$\beta$-Amylase } & \multicolumn{2}{|c|}{$\alpha$-Glucosidase } & \multicolumn{2}{|c|}{ Debranching Enzyme } \\
\hline & $\mathrm{pH} 5$ & $\mathrm{pH} 7$ & $\mathrm{pH} 5$ & $\mathrm{pH} 7$ & $\mathrm{pH} 5$ & $\mathrm{pH} 7$ & $\mathrm{pH} 5$ & $\mathrm{pH} 7$ \\
\hline Koshihikari & $160^{\mathrm{a}}$ & $73^{\mathrm{a}}$ & $0.800^{\mathrm{a}}$ & $0.053^{\mathrm{a}}$ & $243^{\mathrm{a}}$ & $4.7^{\mathrm{a}}$ & $2.67^{\mathrm{a}}$ & $1.98^{\mathrm{a}}$ \\
\hline Nipponbare & $121^{\mathrm{b}}$ & $67^{\mathrm{ab}}$ & $0.782^{\mathrm{ab}}$ & $0.063^{\mathrm{a}}$ & $207^{\mathrm{b}}$ & $3.2^{\mathrm{a}}$ & $1.91^{\mathrm{b}}$ & $1.85^{\mathrm{a}}$ \\
\hline Takitate & $113^{\mathrm{bc}}$ & $88^{\mathrm{ac}}$ & $0.340^{\mathrm{c}}$ & $0.089^{\mathrm{a}}$ & $213^{\mathrm{abc}}$ & $4.3^{\mathrm{a}}$ & $2.14^{\mathrm{bc}}$ & $2.86^{\mathrm{b}}$ \\
\hline M401 & $144^{\mathrm{d}}$ & $72^{\mathrm{abd}}$ & $0.443^{\mathrm{cd}}$ & $0.071^{\mathrm{a}}$ & $216^{\mathrm{bd}}$ & $3.6^{\mathrm{a}}$ & $2.08^{\mathrm{bc}}$ & $2.30^{\mathrm{c}}$ \\
\hline Calrose & $47^{\mathrm{e}}$ & $27^{\mathrm{e}}$ & $0.636^{\text {abe }}$ & $0.069^{\mathrm{a}}$ & $221^{\text {abce }}$ & $2.5^{\mathrm{a}}$ & $1.12^{\mathrm{d}}$ & $0.92^{\mathrm{d}}$ \\
\hline TWR & $21^{\mathrm{f}}$ & $15^{\mathrm{f}}$ & $0.553^{\mathrm{def}}$ & $0.089^{\mathrm{a}}$ & $225^{\text {bcdf }}$ & $3.0^{\mathrm{a}}$ & $0.53^{\mathrm{e}}$ & $0.18^{\mathrm{e}}$ \\
\hline
\end{tabular}

to the other rice samples. These results demonstrate a trend similar to that for $\alpha$-amylase activity. In contrast, the DBE activities of Takitate and M401 rice varieties were higher at $\mathrm{pH} 7.0$ than at $\mathrm{pH}$ 5.0.

Composition of leached sugars during rice cooking In this experiment, the amount of leached sugars and texture were assessed for all samples. The results are shown in Table 2. The amounts of total sugars and reducing sugars ranged from $137.8 \mathrm{mg} / \mathrm{g}$ (M401) to $64.4 \mathrm{mg} / \mathrm{g}$ (TWR), and from 4.54 $\mathrm{mg} / \mathrm{g}$ (M401) to $1.28 \mathrm{mg} / \mathrm{g}$ (TWR), respectively. Weightaverage chain length (CLw) varied from 50.3 (TWR) to 20.5 (Nipponbare). Furthermore, the amount of malto-oligomer was measured as the amount of leached sugars from the $80 \%$ ethanol-soluble fraction obtained from cooked rice (Fig. 2). DP 1 (number-average degree of polymerization) corresponds to the peak area from each sample and showed a wide range, between $88 \%$ (TWR) to $32 \%$ (Takitate). The percentage of DP $2-5$ was $30.8 \%-10.3 \%$, that of DP $6-10$ was $28.8 \%-1.4 \%$, and that of DP 11 was $7.5 \%-0 \%$. The Takitate rice variety had the largest proportion of malto-oligomer content among all the samples, whereas TWR leached a small amount of malto-oligomer.

Table 2. The amounts of total sugars and reducing sugars leached during rice cooking were determined for all samples. Weight-average chain length (CLw) was obtained by dividing the amount of reducing sugars by the amount of total sugars. Means in the same column by the same superscript are not significantly different at $p<0.05$ by LSD test.

\begin{tabular}{lccc}
\hline \multicolumn{1}{c}{ Samples } & $\begin{array}{c}\text { Total } \\
\text { sugars }(\mathrm{mg} / \mathrm{g})\end{array}$ & $\begin{array}{c}\text { Reducing } \\
\text { sugars }(\mathrm{mg} / \mathrm{g})\end{array}$ & CLw \\
\hline Koshihikari & $82.4^{\mathrm{a}}$ & $3.74^{\mathrm{a}}$ & 22.1 \\
Nipponbare & $76.6^{\mathrm{ab}}$ & $3.73^{\mathrm{ab}}$ & 20.5 \\
Takitate & $73.1^{\mathrm{bc}}$ & $2.22^{\mathrm{c}}$ & 32.9 \\
M401 & $137.8^{\mathrm{e}}$ & $4.54^{\mathrm{e}}$ & 30.4 \\
Calrose & $82.6^{\mathrm{ad}}$ & $2.77^{\mathrm{d}}$ & 29.9 \\
TWR & $64.4^{\mathrm{f}}$ & $1.28^{\mathrm{f}}$ & 50.3 \\
\hline
\end{tabular}

Texture of cooked rice The texture of cooked rice is described in Table 3. The hardness ranged from $1.78 \times 10^{2} \mathrm{~N} /$ $\mathrm{m}^{2}$ for Takitate to $4.93 \times 10^{2} \mathrm{~N} / \mathrm{m}^{2}$ for TWR, while the adhesiveness ranged from $0.84 \times 10^{3} \mathrm{~J} / \mathrm{m}^{3}$ for TWR to $27.7 \times 10^{3}$ $\mathrm{J} / \mathrm{m}^{3}$ for Takitate.

Correlation The correlation coefficients between enzymes activities ( $\mathrm{pH}$ 7.0), the amount of leached sugars during rice cooking and the texture of cooked rice are sum-
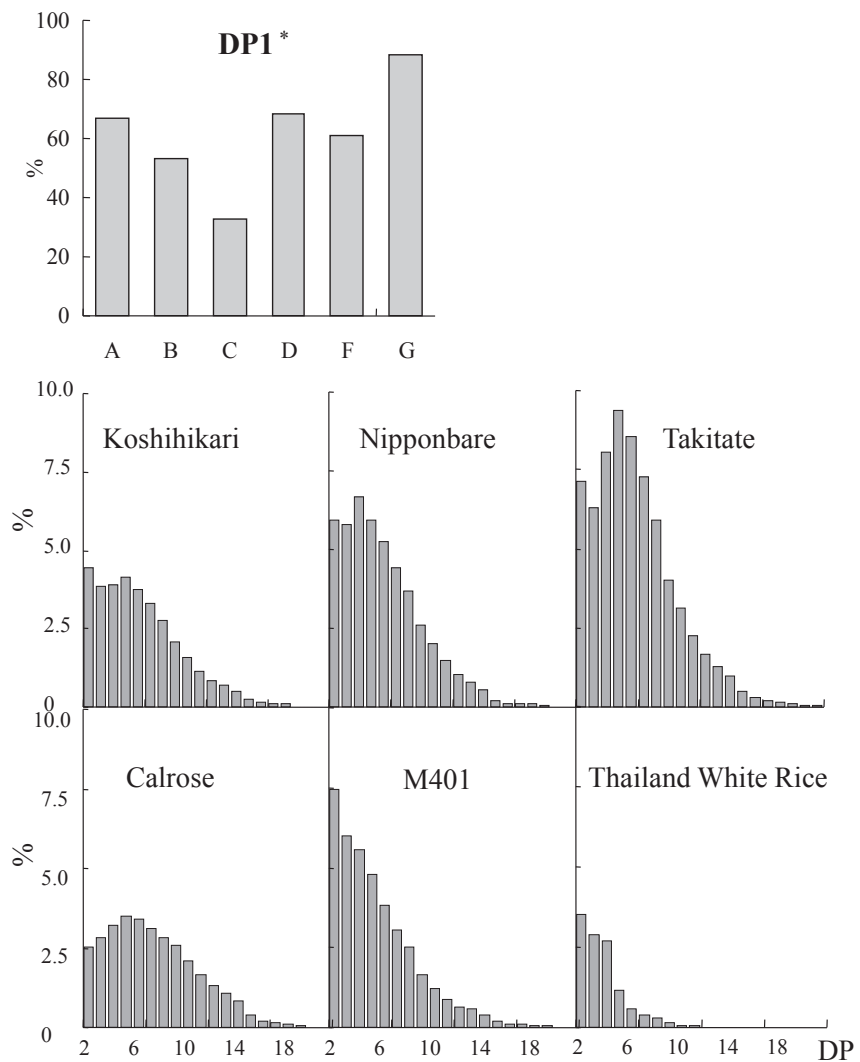

Fig. 2. Malto-oligomer composition in the $80 \%$ ethanol-soluble fraction of leached sugars from rice cooking.

$\mathrm{A}=$ Koshihikari, $\mathrm{B}=$ Nipponbare, $\mathrm{C}=$ Takitate, $\mathrm{D}=$ Calrose, $\mathrm{E}=$ M401, F = Thailand White Rice

${ }^{*} \mathrm{DP}=$ Number-average degree of polymerization 
Table 3. Textures of cooked rice samples. Means for each characteristic with the same superscript are not significantly different at $p<0.05$ by LSD test.

\begin{tabular}{cccc}
\hline Sample & $\begin{array}{c}\text { Hardness } \\
\left(\times 10^{2} \mathrm{~N} / \mathrm{m}^{2}\right)\end{array}$ & $\begin{array}{c}\text { Adhesiveness } \\
\left(\times 10^{3} \mathrm{~J} / \mathrm{m}^{3}\right)\end{array}$ & CLw \\
\hline Koshihikari & $2.11^{\mathrm{a}}$ & $19.2^{\mathrm{a}}$ & 22.1 \\
Nipponbare & $2.46^{\mathrm{ab}}$ & $16.1^{\mathrm{ab}}$ & 20.5 \\
Takitate & $1.78^{\mathrm{ac}}$ & $27.7^{\mathrm{c}}$ & 32.9 \\
M401 & $2.44^{\mathrm{d}}$ & $9.8^{\mathrm{bde}}$ & 30.4 \\
Calrose & $2.52^{\mathrm{abd}}$ & $13.0^{\mathrm{abd}}$ & 29.9 \\
TWR & $4.93^{\mathrm{e}}$ & $0.84^{\mathrm{f}}$ & 50.3 \\
\hline
\end{tabular}

marized in Table 4. No correlation was observed between the four enzymes and the amount of total sugars or reducing sugars leached during rice cooking. However, $\alpha$-amylase activity correlated with the proportion of DP $5-2(0.878, p<0.05)$. DBE activity correlated with the proportions of DP $5-2$ and DP $10-6$ ( 0.909 and $0.829, p<0.05$, respectively).

Moreover, $\alpha$-amylase and DBE activities correlated with rice hardness ( -0.810 and $-0.891, p<0.05$, respectively).

DBE activity correlated positively with rice adhesiveness $(0.817, p<0.05)$. Rice adhesiveness correlated to the proportions of DP $10-6$ and DP $>11(0.889, p<0.05$ and $0.943, p$ $<0.01$, respectively).

\section{Discussion}

In this study, based on the amylase zymogram of milled rice, 4 amylases and 3 DBE isozymes were detected as major bands. Isozyme IV may be the isoform of $\alpha$-amylase in milled rice. Nanjo (2004) isolated and identified 10 $\alpha$-amylase isoforms from germinating rice, and Sakamoto and Maruyama (1990) purified $\alpha$-amylase from milled rice. Isozyme III may be the $\beta$-amylase purified from milled rice by Maruyama (1981). In addition, the isozymes i, ii and iii may be the isoamylases or pullulanases purified from the developing endosperm of rice by Fujita et al. (1991) and Nakamura et al. (1996). However, isozymes I and II are unknown. Thus, it is necessary in the future to examine the endosperm excluding its polymeric protein. The amylase isozymes varied in band pattern and intensity; the amylase bands of TWR were faint and few because the amylase activities were weak. Shimizu et al. (1994) reported differences between brown rice cultivars in the activity of a specific amylase, and indicated that this could explain the relationship between the palatability of cooked rice and proper processing.

The activity of individual amylases in milled rice differs, and this affects the enzyme activities of rice grains during cooking. These activities were observed at neutral $\mathrm{pH}$ during rice cooking. In particular, the $\alpha$-amylase activity at $\mathrm{pH} 7.0$ was maintained at $50 \%$ to $70 \%$ of the activity observed at pH 5.0, and DBE activity was maintained above $80 \%$, except for TWR, whose enzyme activity was approximately $30 \%$. In contrast, the activities of $\alpha$-glucosidase and $\beta$-amylase were approximately $1 \%$ and $10 \%$, respectively, of those at $\mathrm{pH}$ 5.0. The decreases in $\alpha$-amylase and DBE activities at $\mathrm{pH}$ 7.0 were smaller than those of $\alpha$-glucosidase and $\beta$-amylase activities. Thus, it appears that $\alpha$-amylase and DBE activities are induced, thereby decomposing milled rice to the state observed during cooking. Therefore, based on these results, $\alpha$-amylase and DBE activities were significantly correlated with the proportion of malto-oligomer in the leached sugars during rice cooking and to the texture of the cooked rice. In addition, it is thought that endosperm amylases affect the structure of leached starch during rice cooking. Perhaps partially degraded starch affects the adhesiveness of cooked rice. Hanashiro et al. (2004) reported that in comparison with raw rice amylose and amylopectin, leached amylose and amylopectin in cooked rice have approximately $1 / 2$ numberaverage degree of polymerization (DP), and that the chainlength distribution of amylopectin is essentially the same. Moreover, it has been reported that the smaller the amount of leached amylose, the higher the adhesiveness of cooked rice (Hanashiro et al., 2004). Sato and Maruyama (2005) reported that the molecular weight distribution of leached total sugars during rice cooking is lower, and that when a higher concentration of these sugars occurs, the rice taste is evaluated as high.

\section{Conclusion}

We reported that the chain polysaccharide matrix structure of the rice endosperm cell wall is decomposed by the

Table 4. The correlation coefficients between the activities of all the enzymes ( $\mathrm{pH} \mathrm{7.0),} \mathrm{amount} \mathrm{of} \mathrm{leached} \mathrm{sugars} \mathrm{during} \mathrm{rice} \mathrm{cooking}$ $(\mathrm{TS}=$ total sugars, $\mathrm{RS}=$ amount of reducing sugars, $\mathrm{CLw}=$ weight-average chain length and $>\mathrm{DP} 11, \mathrm{DP} 10-6, \mathrm{DP} 5-2, \mathrm{DP} 1=80 \%$ ethanol-soluble fraction of carbohydrate leached in residual liquid during cooking quality test) and the texture of cooked rice $(\mathrm{H}=$ hardness, $\mathrm{A}=$ Adhesiveness) are summarized. * = significant at $p<0.05$, respectively

\begin{tabular}{lrrrrrrrrrr}
\hline & TS & RS & CLw & $>$ DP11 & DP10-6 & DP5 - 2 & DP1 & H & A \\
\hline$\alpha$-Amylase & 0.326 & 0.565 & -0.628 & 0.559 & 0.765 & $0.878^{*}$ & $-0.833^{*}$ & $-0.810^{*}$ & 0.795 \\
$\beta$-Amylase & -0.244 & -0.745 & $0.824^{*}$ & -0.069 & 0.018 & 0.125 & -0.054 & 0.456 & -0.165 \\
$\alpha$-Glucosidase & 0.567 & 0.733 & -0.600 & 0.213 & 0.299 & 0.377 & -0.340 & -0.667 & 0.469 \\
Debranching Enzyme & 0.385 & 0.543 & -0.593 & 0.658 & $0.829^{*}$ & $0.909^{*}$ & $-0.891^{*}$ & $-0.855^{*}$ & $0.817^{*}$ \\
\hline
\end{tabular}


action of endosperm enzymes during rice cooking. Furthermore, rice freshness or cultivar affects the texture of cooked rice (Tsujii et al., 2009).

In this study, we examined the relationships between endosperm amylases, the amount of sugars leached during rice cooking and the texture of cooked rice. Four isozymes from the rice endosperm, amylase and 3 debranching enzymes (DBEs) were detected by the amylase zymogram. The activity of these enzymes differed among rice cultivars. The endosperm amylases appear to decompose the endosperm starch during rice cooking, thereby producing adhesiveness. Assuming that the conformational change of endosperm starch during rice cooking is a major factor in cooked rice palatability, endosperm enzymes could be considered as a remarkable new biomarker for evaluating the palatability of cooked rice. Results from this study will be applied to the breeding of highly palatable rice.

Acknowledgments The authors want to thank Kitoku-Shinryo Co., Ltd. for supplying the rice samples.

\section{References}

Awazuhara, M., Nakagawa, A., Yamaguchi, J., Fujiwara, T., Hayashi, H., Hatae, K., Chino, M. and Shimada, A. (2000). Distribution and characterization of enzymes causing starch degradation in rice (Oryza sativa cv. koshihikari). J. Agric. Food. Chem., 48, 245-252.

Bradford, M.M. (1976). A rapid and sensitive method for the quantitation of microgram quantities of protein utilizing the principle of protein-dye binding. Anal. Biochem., 72, 248-254.

Chikubu, S. (1995). Palatability of cooked rice. In Science of Rice Ishitani, T., and Ohtsubo, K., eds., Asakura Shoten, p117-137 (in Japanese).

Dubois, M., Gilles, K.A., Hamilton, J.K., Robers, P.A. and Smith, F. (1956) Colorimetric method for determination of sugars and related substances. Anal. Chem., 28, 350-356.

Eksittikul, T., Svendsby, O., Yamaguchi, H., Iizuka, M. and Minamiura, N. (1993). Thai rice seed a-glucosidase and its specificity. Biosci. Biotechnol. Biochem., 57, 319-321.

Erwin, B. and Paul, Z. (1989). Biosynthesis degradation of starch in higher plants. Annu. Rev. Plant Physiol. Plant Mol. Biol., 40, 95117.

Fujita, N., Kubo, A., Francisco, P.B., Nakakita, M., Harada. K., Minaka, N. and Nakamura, Y. (1999). Purification, characterization, and cDNA structure of isoamylase from developing endosperm of rice. Planta., 208, 283-293.

Hanashiro, I., Ohta, K., Takeda, C., Mizukami, H. and Takeda, Y. (2004). Leaching of amylose and amylopectin during cooking of rice grains and their effect on adhesiveness of cooked rice. $J$. Appl. Glycosci., 51, 349-354.
Huang, N., Stebbins, G.L. and Rodriguez, R.L. (1992). Classification and evolution of $\alpha$-amylase genes in plants. Proc. Natl. Acad. Sci. USA, 89, 7526-7530.

Ikekita, M., Yajima, H., Murata, T., Takatera, K., Watanabe, T., Sonoyama, M., Tezuka, Y., Ishii, T. and Tarutani, O. (1997). Carbohydrate analysis of porcine thyroglobulin isoforms with different iodine contents. Biochim. Biophys. Acta., 20, 557-565.

Ito, H., Nanatsu, S., Matsui, H. and Chiba, S. (1989). Purification and some properties of two $\alpha$-glucosidases in glutinous rice seed. Denpun Kagaku, 36,181-187.

Kim, J.K. and Wu, R. (1992). Nucleotide sequence of a high-pI rice (Oryza sativa) $\alpha$-amylase gene. Plant Mol. Biol., 18, 399-402.

Laemmli, U.K. (1970). Cleavage of structural proteins during the assembly of the head of bacteriophage T4. Nature, 227, 680-685.

Ohtsubo, K., Nakamura, S. and Okadome, H. (2003). Investigation on estimation of rice palatability by DNA analysis (studies on estimation of rice palatability by DNA analysis part I). J. Jpn. Sc. Food. Sci. Technol., 50, 122-132.

Mahashi, Y., Yabuki, S., Ookura, T. and Kasai, M. (2010). Influence of milling yields on the role of endogenous enzymes in the accumulation of chemical components in rice grains during cooking. The Japan Society of Cookery Science. 43, 237-245.

Maruyama, E., Nagaso, Y., Nakanishi, Y. and Kajita, T. (1981a). Studies on the cooking of rice (part 5) Purification and some properties of active $\beta$-amylase in rice. J. Home. Econ. Jpn., 32, 588-593.

Maruyama, E., Nishi, C., Miyata, Y. and Kajita T. (1981b). Studies on the cooking of rice (part 4) Change in amylase activity during cooking of rice. J. Home. Econ. Jpn., 32, 253-258.

McCleary, B. V. and Sheehan, H. (1987). Measurement of cereal $\alpha$-amylase: A new assay procedure. J. Cereal Sci., 6, 237-251.

Mitsui, T. and Itoh, K., (1997) The $\alpha$-amylase multigene family. Trends Plant Sci., 2, 255-261.

Murata, T., Tanuma, S. and Ikekita, M. (1997a). Structural alteration of cell surface oligosaccharides on HL-60RG cells undergoing apoptosis. Res. Commn. Biochem. Cell Mol. Biol., 1, 249-262.

Murata, T., Shibatsuji, M., Hara, H., Yasuno, S., Yamaguchi, T., Kizuki, K., Hoshino, O., Tanuma, S., Moriya, H, Sweeley, C.C. and Ikekita, M. (1997b). Structural characterization of sialylated and neutral N-linked oligosaccharides labeled with p-aminobenzoic acid octyl ester by high performance liquid chromatography and fast atom bombardment mass spectrometry. Res. Commun. Biochem. Cell Mol. Biol., 1, 285-303.

Nakai, H., Ito, T., Hayashi, M., Kamiya, K., Yamamoto, T., Matsubara, K., Kim, Y.M., Jintanart, W., Okuyama, M., Mori, H., Chiba, S., Sanoa, Y. and Kimura, A. (2007). Multiple forms of $\alpha$-glucosidase in rice seeds. Biochimie, 89, 442-462.

Nakamura S., Okadome H., Yoza K., Haraguchi K. Okunishi T., Suzuki K., Satoh H., and Ohtsubo K. (2004). Differentiation and search for palatability-factors of world-wide rice grains by PCR 
method. Nippon Nogeikagaku Kaishi, 78, 764-779.

Nakamura, Y., Umemoto, T., Ogata, N., Kuboki, Y., Yano, M. and Sasaki, T. (1996). Starch debranching enzyme (R-enzyme or pullulanase) from developing rice endosperm: purification, cDNA and chromosomal localization of the gene. Planta, 199, 209-218.

Nakamura, Y. (2002). Towards a better understanding of the metabolic system for amylopectin biosynthesis in plants: rice endosperm as a model tissue. Plant Cell Physiol., 43, 718-725.

Nanjo, Y., Asatsuma, S., Itoh. K., Hori, H. and Mitsui, T. (2004). Proteomic identification of $\alpha$-amylase isoforms encoded by RAmy3B/3C from germinating rice seeds. Biosci. Biotech. Biochem., 68, 112-118.

Nelson, N. (1944). A photometric adaptation of the Somogyi method for the determination of glucose. J. Biol. Chem., 153, 375-380.

Sakamoto, K. and Maruyama, E. (1990). Purification and some properties of $\alpha$-amylase from polished rice granules. J. Jap. Soc. Starch Sci., 37, 29-34.

Sato, M. and Maruyama, E. (2005). Relation between molecular weight distribution of total sugar in soluble solids of cooked rice and taste evaluation. J. Home Econ. Jpn., 56, 163-169.

Sheehan, H. and McCleary, B.V. (1988). A new procedure for the measurement of fungal and bacterial a-amylase. Biotechnol. Tech., 2, 289-292.

Shimizu, H., Fukui, K., Uehara, Y. and Ohtsubo, K. (1994). Varietal difference of amylase activity in rice seeds. Japan J. Breed., 44, 250.

Somogy, M. (1952). Notes on sugar determination. J. Biol. Chem., 195, 19-23.
Takahashi, N., Shimomura. T. and Chiba, S. (1971). Studies on $\alpha$-glucosidase in rice. Part I. Isolation and some properties of $\alpha$-glucosidase I and $\alpha$-glucosidase II. Agric. Biol. Chem., 35 , 2015-2024.

Tsujii, Y., Kitamura, R., Uchino, M. and Takano, K. (2007). Effect of endospermous amylase on suitability for processing of glutinous rice. Food Pres. Sci., 33, 63-69.

Tsujii, Y., Kiyose, N., Tatsuda, N., Yaguchi, Y., Uchino, M. and Takano, K. (2009). Change in the endospermous cell wall of cooked rice and its effects on the palatability of cooked rice. Food Pres. Sci., 35, 127-134

Yamagata, S., Ito, Y., Tanaka, R. and Shimizu, S. (1988). Gelatinases of metastatic cell lines of murine colonic carcinoma as detected by substrate-gel electrophoresis. Biochem. Biophys. Res., 151, 158-162

Yamaguchi, J., Itoh, S., Saitoh. T., Ikeda, A., Tashiro, T. and Nagato, Y. (1999). Characterization of $\alpha$-amylase and its deficiency in various rice cultivars. Theor. Appl. Genet., 98, 32-38.

Yamasaki, Y. and Suzuki, Y. (1997). Two forms of $\alpha$-glucosidase from rice seeds at the milky stage. Agric. Biol. Chem., 44, 707715.

Yanai, H. (1998). 4-steps Excel statistics. OMS publishing Inc., Saitama, pp151-175.

Yu, S.M., Lee, Y.C., Fang, S.C., Chan. M.T., Hwa, S.F. and Liu, L.F. (1996). Sugars act as signal molecules and osmotica to regulate the expression of $\alpha$-amylase genes and metabolic activities in germinating cereal grains. Plant Mol. Biol., 30, 1277-1289. 